\title{
Secularism and Empire in the United States, 1780-1900
}

\author{
Ryan P. Jordan
}

Department of Social Sciences, National University, 11255 N. Torrey Pines Rd., La Jolla, CA 92037, USA;

rjordan@nu.edu

Received: 15 May 2017; Accepted: 22 June 2017; Published: 28 June 2017

\begin{abstract}
This essay will explore white Americans' use of the rhetoric of church/state separation as a discourse of racial difference during the period from roughly the Revolution to the Spanish American war, when the United States both conquered vast spaces of other people's land, and put forth justifications for national expansion. Over the course of the nineteenth century, white Americans fretted over the assimilability of new groups coming under control of the United States and focused their concern over other groups' fitness for self-government. As will be shown below, religious discussions regarding the extent of people's privatization of religious sentiment, or nascent secularization, figured into this concern about racial fitness. Religious discourses-even those cloaked in defense of "liberal" values such as the separation of church and state-remained an indispensable tool in the construction of a racially exclusive American identity throughout the nineteenth century.
\end{abstract}

Keywords: Church and State-United States; Freedom of Religion-United States; Race RelationsReligious Aspects

Scholars have long recognized the contested legacy of the Revolutionary generation's disestablishment of American religion, given that the United States eventually became a "secular" society simultaneously containing the largest number of self-professed believers in the western world. For historians and legal scholars, the history of the separation between church and state in the United States often involves questions concerning the "original intent" of the founding generation when it came to the role of religion in American civil society; there is also ample scholarship on the legal history of the First Amendment in the two centuries after the drafting of the constitution. Other historians have examined the church/state theme in the context of broader social developments. These range from nativist fears of a church/state union being foisted upon the United States by Catholic immigrants, to discussions of the evangelical battles to close Sunday mail service in the late 1820s, to literature on reactions to the abolitionist movement, or to the birth of the Mormon Church. Scholars have often recognized that when nineteenth century Anglo-Protestants spoke of the "liberal" values of separation, they made such claims with cultural assumptions far less tolerant of groups outside of their caste than those who argued for a "wall of separation" in the twentieth century. ${ }^{1}$

However, historians have not often discussed the separation of church and state, or the privatization of religious sentiment, in terms of the racial and imperial dimensions of American culture. This essay will explore Anglo Americans use of the rhetoric of church/state separation as a discourse of racial difference during the period from roughly the Revolution to the Spanish

1 Recent work on the "original intent" of the founders regarding religious liberty include: Driesbach (2002); Hamburger (2002); Kramnick and Moore (1997); Lambert (2003). Scholarship on the social context of the church/state discourse in the nineteenth century includes: Borden (1984); Hamburger (2002); Hanley (1994); John (1990). On the cultural assumptions of the white Protestant establishment in the nineteenth century, see (Bozeman (1997); Hollinger (1996); Jordan (2012); Marty (1987); Noll (2008); Smith (2003)). 
American war, when the United States both conquered vast spaces of other people's land, and put forth justifications for national expansion. Over the course of the nineteenth century, the dominant white Protestant culture fretted over the assimilability of new groups coming under control of the United States and focused their concern over other groups' fitness for self-government. As will be shown below, religious discussions regarding the extent of people's privatization of religious sentiment, or nascent secularization, figured into this concern about racial fitness. Religious discourses-even those cloaked in defense of "liberal" values such as the separation of church and state-remained an indispensable tool in the construction of a racially exclusive American identity throughout the nineteenth century.

The following essay draws upon a diverse number of controversial texts from roughly the mid-eighteenth century to approximately 1900 to interrogate critically the racialized uses of the church/state discourse, in addition to offering a re-reading of the secondary source literature in the history of religious liberty in the United States in light of newer explorations of the history of race in the United States. ${ }^{2}$ Many scholars of American religious history have examined the growing secularization present in the culture in the nineteenth century, and without denying some trend toward liberalization or secularization, it is still worth reflecting on the ways in which older sectarian prejudice persisted into the 20th century. Among other reasons, such analysis gives insight into the connections between religious or sectarian prejudice and modern forms of racism, a phenomenon linked with imperial conquest. ${ }^{3}$

As put forth by Peter van der Veer and others, the discourses of secularism articulated in Western Europe in the nineteenth century represented a mode of ordering subject peoples, or otherwise creating a reference point for western superiority for metropolitan publics. These scholars point out how supposedly "liberal" or "rational" nation states such as Britain or Holland expressed their national identity with various appeals to an exceptional, liberty-loving, and very Protestant history, even as other scholars can posit a growing acceptance of differentiation in the religious culture of these nations. Nonetheless, the exceptionalism present in certain discussions of religious liberty helped buttress the superiority of westerners when confronting subordinate, colonized peoples, often with the help of a religiously-inspired public sphere that viewed itself as a product of the relative freedom of expression in these countries. Writers, ministers, college presidents, and politicians often justified imperial expansion by highlighting the need to extend the "blessings" of western religious freedom to other less fortunate peoples. Scholars of the nineteenth century U.S. empire, such as Amy Kaplan and Amy Greenberg, have shown how travel narratives, missionary accounts, and popular magazines mobilized anti-Catholic tropes to encourage the kind of national or racial chauvinism associated with "Manifest Destiny" in the nineteenth century, even as their books did not exclusively focus on religion (van der Veer and Lehmann 1999). ${ }^{4}$

An exploration of the religious modes of racial difference yield further insights into the connection between imperial encounters and the creation of "whiteness" within the early American republic. Matthew Jacobson and David Roedieger, for example, have illustrated the fixation of many Anglo-Americans with the unfitness of various non-Anglo-Saxon groups for self-government in the period before 1920. One measure of racial fitness concerned the degree of religious freedom among non-Anglo-Saxon peoples, and it remained unclear if these groups would make good citizens because of their ingrained religious "backwardness". Much of the discussion of the unstable and contested nature of "whiteness" elides easy distinctions between religious and scientific, or modern and premodern in whiteness studies since, for example, the Irish "race" was considered unfit racially

2 In addition to the controversial pamphlets, writings of missionaries, political leaders, or cultural leaders cited in this essay, a larger number of primary source documents used for this paper can be found in my larger study (Jordan 2012).

3 Other interpretations of Protestantism, religious liberty, and secularization at this time include: Schmidt (2002); Wenger (2009); Weiner (2013).

4 On the American empire, see (Botham (2009); Greenberg (2005)). 
in large part because of centuries of ignorance and superstition grafted onto it by the Roman Catholic priesthood. The idea that one's religious values or beliefs represented inherent differences descending with the blood has also been addressed by scholars of anti-Semitism; the fact that national cohesion might be found through eliminating a religious minority speaks to the durability of religion as a marker of racial difference in the modern era (Blum and Harvey 2012; Jacobson 1998; Morrison and Stewart 2002; Roediger 1997). ${ }^{5}$

\section{Anti-Catholicism, Race, and Empire}

For Anglo-Saxon, Protestant Americans living in Revolution's aftermath, one of the oldest set of tropes useful in defining national or ethnic difference involved the fear of Catholic domination and religious tyranny, a tyranny that supposedly preyed upon gullible, ignorant people. The fear of papal or Catholic hegemony provided one of the most significant influences on Anglo-American understandings of the need for a separation between church and state, since Protestants, as a minority in Europe, had long been harried by continental Catholic monarchs. English dissenters further extended anti-papal tropes to a discussion of the tyranny of the established Church of England. Given the popularity of dissenting religious views in the American colonies, it is no surprise that the fear of a Roman Babylon loomed large in the culture of the early American nation, even when Anglo-Protestants were not specifically addressing Catholic or Anglican threats. ${ }^{6}$

For the founding generation, the disestablishment of religion united a broad range of Americans in celebration of an advanced, liberal civilization, a civilization by definition set apart from nearly the entire world. Judah Champion, a Congregationalist minister, when celebrating American religious liberty, referred to the U.S. "as the only great nursery of freedom now left upon the face of the earth." (Champion 1776, p. 24). A similar point was made by the much less religious Joel Barlow, who praised the federal government's lack of favoritism for the Anglican Church as "one of the principal circumstances which distinguishes that government from all others that have ever existed" in terms of the "liberty and happiness" of her people. But in comparing America with the rest of the world, Barlow kept before his reader the threat of priests who "benumbed the inquisitive faculties of the mind," making men "cruel and savage in a preternatural degree." (Barlow 1794, pp. 45-46). Such sentiments reveal the lingering appeal of anti-Catholic, or anti-papal rhetoric among many Anglo-Americans supposedly dedicated to modern projects of purging religion from the state. In the following several decades, men and women as diverse in their outlooks as the deist Thomas Jefferson, to the rabidly anti-Catholic, Samuel F.B. Morse, to evangelical preachers from Lyman Beecher to Alexander Campbell, all celebrated religious freedom as a particularly American freedom, one that grew out of singularly American social or economic advances. Yet as Barlow's views of a menacing priesthood reveal, these Americans also cautioned their countrymen to remain prepared to defend their liberty in a world where spiritual tyranny enslaved minds and souls. Out of this vigilance arose an obsession with the "backward" religious practices of numerous groups confronted by white Americans between 1780 and 1900, be they Native Americans, Mexicans, the Chinese, or Philippinos.

The earliest anxieties over foreign threats to religious liberty focused on the vast "frontiers" to the west of older settlements on the eastern seaboard. For many early Protestant missionaries, travelers, or government leaders, "the West" might be a source for attacks on American liberty if white settlers did not head the call to expand their Christian, republican civilization into the wilderness. Lyman Beecher put forth these arguments in his Plea for the West, written in 1835. Beecher, who was alarmed with increased Catholic emigration to the United States, connected fears of a church/state union with potential imperial threats. In this sermon, Beecher conceived of the West as a battleground

5 For the case of anti-Semitism, see (Fredrickson (2002)).

6 On the fear of the Catholic "other" in British nationalism, see (Colley (2002)). Bernard Bailyn provides a good overview of the Catholic threat in Reference (Bailyn 1967, pp. 246-72). 
between true, enlightened American Protestantism, and backward, tyrannical, oppressive, Old World Romanism: the "religious and political destiny of our nation is to be decided in the West ... the West is a young empire of mind, and power, and wealth, and free institutions rushing up to a giant manhood." But for Beecher the promise of this region would be endangered if "foreign immigrants, unacquainted with our institutions, unaccustomed to self-government" settled the region under the influence of the Austrian Catholic Emperor Leopold and his design to "put down at home and abroad our liberal institutions." (Beecher 1835, pp. 2-3). Such fears did not exist on the eccentric fringe of American public life in the nineteenth century: for example, the best-selling book for much of the late 1830, was the rabidly anti-Catholic "captivity narrative" of Maria Monk, a likely fabricated tale of sexual exploitation and murder in a Canadian convent. ${ }^{7}$

\section{Foreign Frontiers and the Limits of Religious Liberty}

Under the influence of ministers such as Beecher in the early national period, numerous missionaries set out around the world to bring Christian civilization to everyone from unchurched American frontiersmen, to Native Americans, to Asians or Africans. Wherever they went, missionaries pointed out the backwardness of those around them, while also playing up the threats these people might possess for modern, liberal, American values. A good example of this mode of thinking came from the Presbyterian minister and native-American missionary, Narcissa Prentiss Whitman, who conceived of her lonely missionary outpost in Oregon as a bulwark for "the cause of Christ" against the "Romanism (stalking) abroad on our right hand and on our left." This "Romanism" would potentially graft itself onto native superstition to produce a grave threat to American interests in the region: Whitman believed that "Jesuit Papists" were aligning with those of the British and the natives to extend monarchical control over the Willamette valley. And when Whitman and her husband were murdered by the Cayuse Indians who had proven to be difficult converts to American Christianity, the Methodist minister who informed Whitman's parents attributed the natives' actions "to foreign influences, which we have felt coming in upon us like a devastating flood for the last three or four years." 8

When viewed in the context of expansionist literature from the nineteenth century, American religious freedom did not extend to superstitious or heathen beliefs but rather existed solely as a vehicle for a more enlightened civilization-that of the Americans-to check the destructive capacities of others. In the years before and after the War of 1812, for example, white politicians denigrated the revitalization movements led by the Shawnees Tecumseh and Tenskwatawa by raising the specter of "heathenish" or "pagan" religious tyranny at work on the frontier. Such portrayals rejected the idea that the revitalization movements possessed any sort of meaningful social organization or political program among the natives, and focused on how the "sorcerers" or "high priests" of the native tribes played upon the gullibility of their fellow natives to foment violent resistance against white American authority. For one of William Henry Harrison's biographers, the governor of Indiana had to contend with a man, in Tecumseh's brother, the Prophet, who was merely a "shrewd and crafty imposter," a "magician" who availed himself of "the superstition common to all ignorant and uncivilized people" in making them think they had any right to their "lost prairies and hunting-grounds." (Jackson 1840, pp. 63-64). Furthermore, many white leaders assumed that other native leaders could only be "the deluded instruments of their civilized allies [the British]" in advancing a pan-Indian resistance movement (Emmons 1834, p. 57). ${ }^{9}$

Besides explicit imperial threats from political powers, Anglo-Americans found other reasons to fear the melding of Catholic and native superstition on the frontier. The connection between "Roman"

7 On Maria Monk, see (Pagliarini (1999)).

8 Narcissa Whitman to Reverend and Mrs. Allen, August 23, 1842, in Whitman (1986, p. 136); H.H. Spalding to Stephen Prentiss, April 6, 1848, in Whitman (1986, p. 230).

9 General works on Native American "revitalization" include Dowd (1992); Fisher (2012) and Ostler (2004). 
and "native" paganism proved all the easier to make since many indigenous tribes in the lower Mississippi valley, and in what became the American Southwest, had in fact first been converted Christianity by Spanish or French Catholic missionaries. The Reverend James Finley-who saw himself as a veteran of the "great battle between barbarism and civilization in the west"-lamented how Catholic priests had deceived the entire Wyandot nation in Michigan into believing that "to carry a silver cross, and to count a string of beads (was sufficient) to have all of their sins pardoned." But for Finley such nonsense only served to encourage natives in their "superstition and vice." (Finley 1859, p. 233).

Similar comments can be found from many other Methodist ministers, such as George F. Pierce, who in 1850 compared the "debauched strongholds" of Romanism in places like St. Louis, San Antonio, or Santa Fe with the "thralldom" of native spirituality. Both required the urgent reforming zeal of American missionaries (Pierce 1857, pp. 20-21). These men always made clear, as did the Methodists Daniel Lee and Joseph Frost, that they did not "favour the union of church and state" when arguing for missionary activity, but rather wanted their accounts to encourage settlers to being "wholesome civil laws" and other agents of civilization to the frontier (Lee and Frost 1844, pp. 319-20). Even the painter George Catlin - who visited the frontier without any religious or missionary intentions in the 1840s—and who supposedly lamented the destruction of native tribes, wrote how "among ignorant, and consequently superstitious people," mysteries retarded many developmental aspects of society. For Catlin, the medicine man, an individual Catlin viewed as a kind of sorcerer, duped his gullible subjects into believing he was a "high priest," and held the same kind of political or civil power "as chiefs in the councils of the nation." Catlin wrote disparagingly of the high priests as "great octroi" who manipulated all members of the tribes, including the chiefs, for various forms of tribute (Catlin 1853, p. 87).

\section{Missionaries and the Uses of Liberal Religion}

When alerting easterners to the religious and social dangers of an uncivilized western frontier, many popular journals of the nineteenth century called upon women to exhibit for the world how the beneficent influences of American Protestant Christianity, when carried into every social, civil, and political institution, could radically transform those on the receiving end of such benevolence. For the editors of Godey's Ladies Book, the idyllic vision of Christian women and mothers planting New England civilization demonstrated how the "anarchy" of the frontier could be peacefully transformed by enlightened Americans, if they would only find courage to accept the challenge. The violent processes of expropriation of native land and military expansion was subsumed beneath a vision of New England schools and churches being peacefully planted by mothers, who represented an "empire" of American women. Of most importance, these women had been properly freed from "code, creed, or caste ... to worship God in spirit and truth," since in America "religion is free."10 As agents of the liberty-loving, voluntaristic American religious culture, missionaries saw their role throughout the world as one of bringing a combination of religious, social and economic progress to the "heathen." The Reverend G.H. Wheeler, a missionary in eastern Turkey, explained his view of the social and political benefits of missionary work: "the material advantages which intelligence has over ignorance, industry over idleness, and virtue over vice" were all examples of Christianity's great advantage "over all false systems." Christian missions was as much advocated the cultural and social acceptance of Anglo-Saxon superiority, in addition to spiritual conversion. The ABCFM made explicit the racial meaning of "Christianity": "the migratory and colonizing character of the Anglo-Saxon peculiarity adapt them for the work of missionaries ... God has appointed us to be a missionary people."11

10 Quote from Godey's Ladies Book in Kaplan (2002, p. 40).

11 Quotes from Wheeler and the ABCFM in Schueller (2003, pp. 158-59). 
But oftentimes for missionary supporters, a proper separation of church and state represented the greatest gift of American civilization to the world. The Presbyterian college president, George Junkin, at his inauguration at Washington College in Virginia, explained the moral superiority of Protestant college students and future missionaries who were the product of American religious freedom. Colleges, as institutions of the church, not of the state, represented a superior moral force to any emanating from the state because it is able to "overcome evil with good," while the justice of the state merely "checks evil with evil." Junkin depicted the development of private colleges as representing progress over the "assumption of the pagan and modern Erastian idea, that the civil government has dominion also in matters of religion." This assumption led to the unholy alliance of church and state, as well as to a "ruling spirit of despotism" in both church and state. Furthermore, such union retarded the proper development, not only of religion, but also all literature and science (Junkin 1849, p. 23).

Junkin then praised the missionary efforts of many of the students who attended religiously-instructed colleges, efforts that served as "the lights of science and literature to the Pagan world ..." The separation of the civil power from that of the church had given birth to an advanced civilization that was then enabled to uplift the entire globe. Junkin told his audience to "look to the mission schools at Serampore, at Calcutta, in Ceylon ... at Allahabad, in the Isles of the Great Pacific, over the whole earth" and see that this "light of science" has advanced "where the Bible throws its light into the soul." (Junkin 1849, p. 29). The Protestant mission of teaching people to think for themselves, of throwing off popish or other dark tyrannies was the conduit for a wide range of scientific and social improvements. The thoughts of Junkin about the connection between Protestant evangelicalism and science remind historians of the belief that scientific progress was dependent upon a proper respect for God's natural laws for the intelligentsia of America's colleges in the nineteenth century. And as they looked out around the globe at a myriad of benighted races and people, members of the WASP establishment, like Junkin, believed American, Protestant civilization represented a mode of unlocking God's laws through rational, private investigation of the Bible. This book, placed into the hands of every believer by reformed Protestants, would encourage men and women to "understand the same God who had designed Creation" and stimulate "further and direct exploration of nature," given the assumption that the natural world backed up biblical orthodoxy (Bozeman 1997, p. 128).

The racialized limitations of early American's "liberal" understanding of church/state relations extended beyond ministers such as Junkin to include the intellectual heirs of Thomas Jefferson, a man accused in his own of time of being an atheist. The Sunday Mail's controversy of 1829-1831—during which evangelicals failed in their attempt to close postal services on the sabbath-is often seen as a triumph of the secular, Jeffersonian tradition in the early republic. The main individual involved in asserting Jefferson's "wall of separation" during the congressional debates against the evangelicals, was Senator Richard Johnson, a man who had also made a name for himself as a brave "Indian fighter" reputed to have killed the pan-Indian leader Tecumseh. When running for Vice-President as a Democrat in 1832, Johnson's supporters explicitly linked Johnson's fight against sabattarian "bigots" in the Senate with his earlier fight against "the savage foe-Tecumseh." It was, as Col. Ely Moore put it, "the same sacred love of country that prompted Col. Johnson to face the country's open foe on the battle field, (that) urged him with equal ardor to grapple with [the nation's] secret enemies in the Senate Chamber." Moore continued, "we behold in Johnson not only the tried and invincible soldier" but also the "dauntless asserter of the rights of conscience." Another celebratory pamphlet published around the time of Johnson's campaign again linked American religious freedom with the dispossession of native land. Its author, William Emmons trumpeted Johnson's forbears as men "free from religious superstition, cant, and priestcraft," who, in Kentucky fearlessly endured savage attacks in Kentucky to plant "civilization, and civil and religious liberty." (Moore 1833, pp. 8, 90-91).

\section{Church/State Discourse and the Native American Ghost Dance}

Later in the nineteenth century, Americans again had to grapple with the racial meaning of religious freedom when confronting Native American resistance on the frontier, this time with the 
so-called "Ghost Dance" on the Great Plains. Repeatedly white Americans justified their government's distaste for the American Indians' religious freedom to take part in these ceremonies, and many Indian agents continued to deprecate native spirituality as superstition that performed no useful social purpose. But soldiers primarily feared that the medicine men or other leaders of the ghost dance would whip up large numbers of Indians into a supposedly superhuman frenzy that could then overwhelm the detachments on what was already a militarized and violent frontier. Indian agent Stanton Fisher, stationed at Fort Hall, Idaho in 1889, complained about the "superstition" of natives who had become "insolent and sullen, and through the secret influence of the so-called "medicine men" were led to believe that all white men will soon die, and that all the dead Indians will be resurrected." (Smoak 2006, p. 183) The response needed to be met with increased military presence and arrests. Although Fisher's view came to be the dominant one, other white Americans did recognize the hypocrisy of denying Native American liberty while claiming to bring civilization to the Plains. For a Lieutenant Hugh L. Scott, if agents stopped the dances, it would seem to the Indians as "a violation of those rights common to every human being," included in those being the "right of each person without contravening the law to worship God according to the dictates of his own conscience." In a similar vein, former Pine Ridge agent Valentine McGillycuddy criticized the Army for holding non-whites to higher standards than whites when it came to the subversive nature of "apocalyptic" religious belief, such as that contained in the Ghost Dance: "If the Seventh Day Adventists prepare their ascension robes for the second coming of the Saviour, the United States Army is not put in motion to prevent them. Why should not the Indians have the same privilege?" (Ostler 2004, pp. 279, 309). On the other hand, many Army leaders and other civilian agents in the Plains and Rockies felt quite comfortable denying that native "religion" even was "religion" in any civilized or western sense. J.G Critchlow, for example, in an 1872 report to Congress dismissed native spirituality as "exceedingly vague": though they had some notion of a supreme being, as with all "barbarous and savage nations" such definitions were hardly on a par with more refined western theology (Niezen 2000, p. 129). By 1882, the U.S. Department of the Interior defined the Ghost Dance as seditious, and began to prosecute people who practiced the dance in public. But the decision of the Interior Department, it should be remembered, came even as President Grant recognized the ideal of religious competition regarding proselytizing efforts in the region. Religious freedom in this case was intended only so far as to help buttress Christianity against the non-Christian (Beaver 1966).

Native Americans understood the need to explain how their religious beliefs deserved as much protection from "American" religious freedom as any other white religious minority. Increasingly in the nineteenth century, native leaders also tried to explain to whites how their religious beliefs would not lead inevitably to social dislocation, or war, as so easily suspected by white missionaries or military leaders. A practitioner of the Sioux Ghost Dance, Torn Belly, protested that he did not know why troops had been sent to his reservation: "We don't want to fight ... this is our church. It's just the same as the white man's church except that we don't pass around the hat." Sitting Bull tried to explain to missionaries that native religion and Christian religion were, in the words of white missionary Aaron McGaffey Beede, equal manifestations "of a fundamentally Catholic religion." Such a view also led to syncretic practices on the part of natives who had for decades encountered white missionaries. Sitting Bull explained, for example, that he viewed the Virgin Mary "as a human incarnation of that mystical 'Mother' whom all the old-time Dakotas were taught to adore." These answers, of course, disturbed Protestant missionaries who shared nothing of the syncretic-even relativistic-mentality of a Sioux leader like Sitting Bull. In the end, for all of their philanthropic interest in "saving" the Indian, Sitting Bull only saw the missionaries as "in some way leagued with the U.S. government in crushing the Dakota nationality." (Ostler 2004, pp. 192-93, 311). ${ }^{12}$

12 On these points see also (Berkhofer (1965)). 


\section{Mormons and the Protestant Empire}

Perhaps second only to Native Americans as a western threat in need of suppression from the nineteenth-century American government were the Mormons. Because the corporate nature of the church established banks and other property under church authority, the Mormons seemed to be another manifestation of Catholic spiritual tyranny. But nineteenth century Americans attached even more concern to the church's "heathenish" practice of polygamy. One of the most significant Supreme Court cases of the nineteenth century addressing the "wall of separation" between church and state, Reynolds v. United States (1879), denied first amendment protection to Mormon polygamy by declaring that polygamy was a feature of "Asiatic and African people." The court went on to state that when Virginia first disestablished religion, it also passed customary English legislation, characteristic "of civilized nations" forbidding polygamy. The justices reminded the Mormons that those who disestablished religion in Virginia did not intend for the "patriarchal principle" inherent in polygamy to leave people in the "fetters ... of stationary despotism," again contrasting American religious freedom against despotic regimes. The court also explained its distaste for the inclusion of polygamy under the protection of the first amendment by connecting Mormon polygamy to the "uncivilized" case of Hindu numerous women who believe it was "her duty to burn herself upon the funeral pile of her dead husband." The first discussion of the meaning of the separation of church and state as it applied to federal power over states (or territories), then, used familiar Protestant language of cultural and racial difference, and focused on certain people's unfitness for the legal protection of religious freedom. ${ }^{13}$

Sarah Barringer Gordon's work both on the law of blasphemy in the nineteenth century courts, as well as on legal statutes addressing the "Mormon Question," further testifies to the fears of many legal scholars and judges in the nineteenth century regarding the nagging threats of "infidelity" to a republic of disestablished churches. Although Americans celebrated the ways in which disestablishment created a voluntary commitment for the creation of schools and churches, they intended for this voluntary ethic to aid and sustain a broad-based commitment to Protestant republicanism, not to be abused by groups such as the Latter-Day Saints. As Gordon demonstrates, case law based on English common law influenced the Supreme Court's ruling that Mormons could be subjected to territorial restrictions in Oklahoma regarding voting and holding office, in addition to earlier proscriptions of polygamy in Utah (Gordon 2002, pp. 690, 704-8).

The dominant Protestant culture of the nineteenth century could also find plenty of other reasons to fear the "license" of Mormon appeals to First Amendment protection; in particular the backward spiritual and sexual practices might be able to appeal to the particularly "gullible" among the United States' nonwhite racial groups, especially Native Americans and African-Americans, or even the Chinese. A recurring accusation when the Mormons lived in Missouri, for example, was that Mormons might begin attracting both African-Americans and Native Americans to the fold in order to pursue a larger attack on the white Protestant citizens of the territory. An editorial in Missouri accused Mormons of "secretly tampering with the neighboring Indians to induce them to aid in the event of open hostility" while also raising the prospect of an alliance between free blacks and Mormons in efforts to foment slave rebellions in nearby states (Daily Missouri Republican 1833). In the 1860s, an editorialist in New York feared that the Latter-Day Saints might also create problems for an American federal government trying to manage the African-American "problem" in the post-Civil War South. This fascinating editorial made an explicit link between perceived Mormon and African superstition and debauchery. "The strongest tendencies of the Negro character to miscellaneous sexual indulgence, and the powerful instinct of the race toward unreasoning superstition" would irresistibly "draw them to the faith." The editorialist further claimed that an acceptance for the institution of polygamy supposedly "descended with the blood" among African-Americans. Given this fact, the proselytizing

13 Reynolds v. United States, 98 U.S. 145 (1879), pp. 162,164; see more generally (Gordon 2002). 
zeal of the Mormons, a zeal that would flood the South with other carpetbaggers, would encourage blacks "to mingle sexual indulgence with religious solemnities" and thus create a peril for the nation even worse than that of "Asiatic migration on our Pacific coast" (New York World 1865) ${ }^{14}$.

\section{Asian Religion, Church, and State}

And it was this concern with "Asiatic peril" that gives the historian a further glimpse at the cultural and racial uses of the discourse of religious privatization in the nineteenth century. All sorts of epithets were thrown at the East Asian arrivals, often by political, educational, or business leaders in Washington, Sacramento, or San Francisco. Beginning in the 1870s and culminating in the 1882 Chinese Exclusion Act, Californians as well as the wider American public began to "investigate" the character of these largely unwelcome immigrants who were arriving into the same western frontier (California) that whites had wrested from Native Americans. Indeed white leaders worried that all of the "progress" made in "saving" the West from barbarism would come to nought if another uncivilized group (the Chinese) gained entry to the United States. The resulting "investigations" of the "Chinese problem" mobilized numerous popular prejudices and ethnic stereotypes regarding Chinese criminality, subservience, sexual deviance, and unhealthy hygiene. A joint House and Senate Investigation in 1877 also sought at various points to bar the Chinese by virtue of their superstitious religious beliefs that supposedly destroyed individual freedom and led to the oppression of women. The constant references to Chinese "slavery" or "cooleyism" drew upon numerous western Christian prejudices to highlight the superiority of-as one author put it—the "civilization of Christ" over the "civilization of Confucius." (Wong 1998, p. 8) Several individuals who testified before Congress went to great lengths to explain the superiority of "American" or "western" religion over the oppressive "pagan worship" of the Chinese. Even defenders of Chinese immigration, such as the Reverend Augustus Loomis, a leading American missionary to China, could not help but conceive of American citizenship as being mainly limited to what he termed the "Christianized Chinamen who make good citizens of this republic," and should not be placed in the hand of just any "heathen" emigrant from east Asia (United States Congress 1887, p. 28). ${ }^{15}$

Those who, unlike Loomis, opposed any further Chinese immigration—such as onetime California Attorney General Frank Pixley—often made clear how American "religion," was one and the same with a kind of providentialist nationalism that limited American citizenship to whites. Pixley spoke of the Chinese as "superstitious ... idolatrous" people who did not practice what he termed "our religion." When Pixley was asked during the 1877 investigations to define exactly "our" religion, the San Francisco representative informed Congress that the "American" religion claimed the providential right of the white race to live on the North American continent, and that God had commanded that other weaker races, such as the Native Americans be displaced by this stronger race. As for the Chinese, since they are "not a favored people they are not permitted to steal from us what we robbed the American savage of" (United States Congress 1887, pp. 27-28).

As Pixley and Loomis' comments demonstrate, both sides of the white debate over the Chinese assumed the inferiority of Asian religious culture, and even some Chinese-Americans assented to the view of Confucian or Buddhist beliefs as "backward." But several Chinese-American leaders publicly protested such attitudes. One important defense of Chinese religious culture entitled "Why I am a Heathen," appeared in the North American Review in 1887. Its author, Wong Chin Foo, sought to counter the arguments of Yan Phou Lee, who had earlier published the article explaining the need for the Chinese to embrace Christianity as a superior social and cultural system. Wong understood the importance of religious institutions and religious culture as handmaidens of American racial

\footnotetext{
14 Other histories of Mormon persecution in the mid-nineteenth century can be found in Firmage and Mangrum (1988); and Furniss (1966).

15 On Chinese and Asian immigration more generally, see (Takaki (1998)).
} 
chauvinism in the period, as for example he noted with distaste the attitude of the Philadelphia Evening Bulletin regarding how "Christianity has developed astonishing civilization among those races that adopted it. Buddhism meanwhile has kept all of its professed peoples in a condition of semi-barbarism." (Wong 1998, p. 45) In response, Wong reminded the supposedly civilized Christian missionaries of all of the ways in which an overly individualistic, selfish, and materialistic society was inferior to an ancient civilization, like that of the Chinese, which possessed a far stronger communitarian ethic. Wong also compared the "heathen" in China favorably against the white laborers in New York City who were forced to "elect those who betray them" through machine politics. "How is this better than the disfranchised Asiatic peasantry?" asked Wong. As for the American missionaries seeking to bring a higher civilization to the Chinese, Wong highlighted the narrow parochialism of the men and women who traveled around the world damning souls, complaining of others "semi-barbarism," all the while failing to understand anything about the religion of Confucius or Buddha. Wong found missionaries constantly exaggerating the "backwardness" of Chinese peasants as a way of furthering their own careers or interests. Not unlike Sitting Bull among the Sioux, Wong believed that missionaries furthered American economic interests by encouraging white Americans to believe in others' incapacity for self-government. These arguments, however, did little to prevent Congress from reapproving anti-immigration statutes against the Chinese in the years ahead (Wong 1887, p. 177).

\section{Religious Liberty, Anglo-Saxonism and Manifest Destiny}

As Frank Pixley made clear in the Congressional Hearings on Chinese immigration, the familiar nineteenth century belief in America's providential mission to possess more and more land provides another important imperial context for American understandings of religious freedom. John L. O'Sullivan's 1839 discussion "of the worship of the most high" dovetailed with a belief that religious freedom needed to be one of the gifts bestowed upon the "disorderly house" of Mexico. The common metaphor of an American biblical temple coextensive with the globe is a reminder how the Anglo-Protestant evangelical, missionary culture informing someone as ostensibly "secular" as John O'Sullivan united him with far more evangelical women such as Catherine Beecher or Sarah Josepha Hale. As Amy Kaplan has demonstrated, the rhetoric of manifest destiny, as well as that of women's domesticity so prevalent in the nineteenth century, "shared a vocabulary that turn(ed) imperial conquest into spiritual regeneration in order to efface internal conflict or external resistance" with appeals to national or global harmony (Kaplan 2002, p. 31).

Men like O'Sullivan excused an invasion of Mexico in the name of progress, and mouthed familiar anti-Catholic diatribes about the backward religious attributes of Mexicans. The Philadelphia Daily Sun, in its 1846 support for an aggressive foreign policy against Mexico, portrayed Mexican Catholics as needing liberation from religious bondage: "if we look towards Mexico, we are menaced by ... eight millions of people ... steeped in the worst of all superstitions, and slaves to the tyranny of monks." The paper then termed it only natural that Americans would want to diffuse "our own system of government on every enslaved people," a system that included "the right to worship God according to their own conscience." The Daily Sun's editorial omission of the reality of American slavery in Texas also spreading with America's supposedly "just" empire speaks to the purposefully misleading, if not delusional, nature of America's ideology of Manifest Destiny in the mid-nineteenth century. ${ }^{16}$

Texas settlers, or prospective Texas settlers, had long linked their right to take their slaves into Texas with assurances that they could also take their Protestantism into the Catholic nation of Mexico. More than one prospective settler to Texas from the slaveholding South asked about religious freedom and their rights to hold slavery in the same sentence. From Alabama, in 1824, came a letter from Richard Royall to Moses Austin which linked Mexico's dislike of slavery and its Catholic establishment

16 Quoted in Greenberg (2005, p. 98). General works on the ideology of Manifest Destiny include Horsman (1981); and Stephanson (1995). 
"as the two obstacles that retard emigration." Later on, many Texans appreciated the value of making a point of Mexican's Catholic backwardness when trying to get Northern American support for annexation, while downplaying the fact that this "papist" republic had managed to abolish slavery. In 1835, Branch T. Archer explained his cause to other Americans thusly: "our cause is that of Liberty, Religious toleration and Freedom of Conscience against Usurpation, Despotism, and the Unnatural and Unholy Monopolies of the Church of Rome."17

As students of nineteenth century popular culture have discovered, travel narratives from the mid-nineteenth century repeated the numerous tropes and stereotypes regarding the backward "Latin" Catholic Church, accounts that worked to encourage American military and economic imperialism in Mexico and Latin America. Repeated accounts of American men standing up for themselves when their hats were knocked off by "arrogant" priests carrying the Eucharist in front of "slavish" crowds, or of the hypocrisy of the "flashing eyes" of women in convents who were supposedly dedicated to lives of celibacy, reveals how many Americans encouraged cultural animosity toward their southern neighbors on grounds of religious inferiority (Greenberg 2005, pp. 100-25). But Latin Americans themselves often understood the Protestant context for American denunciations of the church/state union, and could articulate their own critiques of the limitations of America's liberal culture. Many Mexican and South American editorialists cited how American liberties came at the expense of slaves, Native Americans, as well as Mexicans. Liberal admirers of American religious freedom in central and South American, who sought to transplant those ideas onto their own soil, had to qualify their admiration for disestablished churches when faced with expansionists such as James Polk. According to Gene Brack, the Liberal Mexican paper, El Siglo, strongly denounced the "Protestant, calculating, (and) businesslike" Yankee culture as one that lacked respect for other civilizations, and gave no thought whatsoever to improving the condition of the conquered over which they governed (Brack 1970; Pinheiro 2014). A later editorial in El Siglo spoke of how for North Americans "utility is their God and material prosperity their dogma." (Arguello 1995, p. 101) The Mexican War minister Tornel y Mendivil looked upon American liberal declarations of progress and freedom as simply another manifiestions of the impulsive of Nordic "barbarous hordes" who had always plowed under "whatever has stood in the way of (their) aggrandizement." Tornel y Mendivil also referred to the demands made by Protestant settlers for "religious toleration" as a right "even superior to that of conquest," because it often betrayed a lack of respect for Mexican Catholicism. ${ }^{18}$

But the North Americans would continue to justify imperial expansion by making appeals to the superiority of "American religion" or of American religious settlements, such as the separation of church and state. They would also do so by rediscovering their British, "Anglo-Saxon" heritage that linked confident American expansionism to British imperialism. By the end of the nineteenth century, Josiah Strong proudly asserted how the Anglo-Saxon's religion was "more vigorous, more spiritual, more Christian than that of any other." ${ }^{\prime 19}$ As part of the desire of men like Strong to see the whole world, "Anglo-Saxonized" American, Protestant Christianity could transform weaker races and nations into enlightened societies. As Paul Kramer reminds us, the discourse of "Anglo-Saxonism" connected nineteenth century propagandists of empire with eighteenth century providentialists by an appeal to a certain British heritage of liberty; older constructions of a superior Protestant civilization still held sway even among men and women sometimes given to a reliance upon social Darwinian rationalizations for others' failure in the race of empires (Kramer 2003; Kidd 2013). In this way, when Americans embarked on their first attempt at formal overseas empire in the 1890s, they could mobilize very familiar ideas about religious and racial difference. For example, in 1899, the Outlook hoped that the American government would extend all of the blessings of local government embodied in the American constitution to the Philippines, including what the paper termed "the American

\footnotetext{
Quotes from Miller (1988, pp. 299, 313). See also (Foote (1841, pp. 136-50)).

Tornely Mendivil quoted in Castaneda (1970, p. 295), See also ((McGuiness 2003)).

Strong quote from Marty (1987, pp. 245-46).
} 
Church," particularly as the "Spanish" church had taught nothing "but disrespect for the law." A liberalized understanding of the relationship between believers and the state embodied in the "American Church" had much to teach the rest of the world, even as the paper admitted that the lesson of "self-government" was not easily taught: "it took eight centuries of conflict in England, and two of privation and peril in America" in order for Anglo-Saxons to develop an "ideal" social and political state. ${ }^{20}$ Other editorialists felt that only the strong arm of American military power could aid in the social improvement of the Philippine islands. An editorial in the Woman's Journal hoped that "medieval Christianity, Mohammedianism, (and) heathenism" would go the way of misguided insurgents such as (the seventeenth century native American) "king Philip, or Sitting Bull, or Nat Turner" who tried to stop "the progress of mankind." 21

\section{Conclusions}

The seamless connections made between religious liberty, racial difference, and imperial conquest formed a mainstay of expansionist thinking in the late eighteenth and nineteenth centuries. It was an expression of certain white Anglo-Saxon cultural outlook present among those in control of America's colleges, leading publications, and legal and political institutions. Those who stood outside of this culture-such as Native Americans, Chinese immigrants, or Mexicans, recognized the limitations of American notions of the privatization of religious sentiment. These limitations speak to the need for historians to situate supposedly universal or natural rights, such as those of conscience, in a specific national and racial setting. Prevailing Anglo-American thinking on the separation of church and state in the 1800s retained its connection to broad-based fears of Catholic or papal tyranny from the 18th century; such thinking could also be mobilized in a transatlantic justification of Anglo-Saxon empire building and white racial superiority.

Conflicts of Interest: The author declares no conflict of interest.

\section{References}

Arguello, Rosa Suarez. 1995. Un Mirador a Estados Unidos: La Prensa de la Ciudad de Mexico despues de la Invasion. In Estados Unidos Desde America Latina: Sociedad, Politica, Cultura. Edited by Ana Arguello and Victor A. Arriaga Weiss. Mexico City: Colegio de Mexico.

Daily Missouri Republican. 1833. The Disturbances in Jackson County. Daily Missouri Republican, December 20. New York World. 1865. Negro Suffrage and Polygamy. New York World, October 12.

Bailyn, Bernard. 1967. The Ideological Origins of the American Revolution. Cambridge: Harvard University Press. Barlow, Joel. 1794. Advice to the Privileged Orders, in the Several States of Europe. London: Cornell University Press. Beaver, R. Pierce. 1966. Church, State, and the American Indian. St. Louis: Condordia Publishing.

Beecher, Lyman. 1835. A Plea for the West. Cincinnati: Truman and Smith.

Berkhofer, Robert J., Jr. 1965. Salvation and the Savage: An Analysis of Protestant Missions and American Indian Response, 1787-1862. Lexington: University of Kentucky Press.

Blum, Edward J., and Paul Harvey. 2012. The Color of Christ: The Son of God and the Saga of Race in America. Chapel Hill: University of North Carolina Press.

Borden, Morten. 1984. Jews, Turks, and Infidels. Chapel Hill: University of North Carolina Press.

Botham, Fay. 2009. Almighty God Created the Races: Christianity, Interracial Marriage, and American Law. Chapel Hill: University of North Carolina Press.

Bozeman, Theodore Dwight. 1997. Protestants in an Age of Science: The Baconian Ideal and Antebellum American Religious Thought. Chapel Hill: University of North Carolina Press. Chapel Hill: University of North Carolina Press.

Brack, Gene. 1970. Mexican Opinion, American Racism, and the War of 1846. Western Historical Quarterly 18: 172. [CrossRef]

20 (Outlook, 26 August 1899, p. 934).

21 Woman's Journal, 8 April 1899, p. 106). 
Castaneda, Carlos. 1970. The Mexican Side of the Texan Revolution. Austin: Graphic Ideas.

Catlin, George. 1853. Life among the Indians. London: Gall and Inglis.

Champion, Judah. 1776. Christian and Civil Liberty. Hartford: E. Watson.

Colley, Linda. 2002. Britons: Forging the Nation, 1707-1837. New Haven: Yale University Press.

Dowd, Gregory Evans. 1992. A Spirited Resistance: the North American Indian Struggle for Unity, 1745-1815. Baltimore: Johns Hopkins University Press.

Driesbach, Daniel. 2002. Thomas Jefferson and the Wall of Separation between Church and State. New York: New York University Press.

Emmons, William. 1834. Authentic Biography of Col. Richard M. Johnson of Kentucky. Boston: A. Langworthy.

Finley, James B. 1859. Life among the Indians, or Personal Reminiscences and Historical Incidents Illustrative of Indian Life and Character. Cincinnati: Curts and Jennings.

Firmage, Edwin B., and Richard Collin Mangrum. 1988. Zion in the Courts: A Legal History of the Church of Jesus Christ of Latter-Day Saints, 1830-1900. Urbana: University of Illinois Press.

Fisher, Linford. 2012. The Indian Great Awakening: Religion and the Shaping of Native Cultures in Early America. New York: Oxford.

Foote, Henry Stuart. 1841. Texas and the Texans, or the advance of Anglo-Americans to the South-West. Philadelphia: Copperthwaite and Co.

Fredrickson, George. 2002. Racism: A Short History. Princeton: Princeton University Press.

Furniss, Norman. 1966. The Mormon Conflict, 1850-1859. New Haven: Yale University Press.

Gordon, Sarah Barringer. 2002. The Mormon Question: Polygamy and Constitutional Conflict in Nineteenth Century America. Chapel Hill: University of North Carolina Press.

Greenberg, Amy. 2005. Manifest Manhood and the Antebellum American Empire. Cambridge: Cambridge University Press. Hamburger, Philip. 2002. Separation of Church and State. Cambridge: Harvard University Press.

Hanley, Mark. 1994. Beyond a Christian Commonwealth: The Protestant Quarrel with the American Republic. Chapel Hill: University of North Carolina Press.

Hollinger, David. 1996. Science, Jezws, and Secular Culture: Studies in mid-Twentieth Century American Intellectual History. Princeton: Princeton University Press, pp. 10-40.

Horsman, Reginald. 1981. Race and Manifest Destiny: The Origins of American Racial Anglo-Saxonism. Cambridge: Harvard University Press.

Jackson, Issac. 1840. Life of William H. Harrison, the People's Candidate for the Presidency. Philadelphia: Marshall, Williams, and Butler.

Jacobson, Matthew. 1998. Whiteness of a Different Color: European Immigrants and the Alchemy of Race. Cambridge: Harvard University Press.

John, Richard R. 1990. Taking Sabbatarianism Seriously: The Postal System, the Sabbath, and the Transformation of American Political Culture. Journal of the Early Republic 10: 517-67. [CrossRef]

Jordan, Ryan P. 2012. Church, State, and Race: The Discourse of American Religious Liberty, 1750-1900. Lanham: Rowman and Littlefield.

Junkin, George. 1849. Christianity: The Patron of Literature and Science. Philadelphia: Board of Trustees, Washington and Lee University.

Kaplan, Amy. 2002. The Anarchy of Empire in the Making of U.S. Culture. Cambridge: Harvard University Press.

Kidd, Thomas S. 2013. American Christians and Islam Evangelical Culture and Muslims. Princeton: Princeton University Press.

Kramer, Paul A. 2003. Empires, Exceptions, and Anglo-Saxons: Race and Rule between the British and U.S. Empires, 1880-1910. In The American Colonial State in the Philippines: Global Perspectives. Edited by Julian Go and Anne L. Foster. Durham: Duke University Press.

Kramnick, Issac, and R. Laurence Moore. 1997. The Godless Constitution: The Case Against Religious Correctness. New York: Norton.

Lambert, Frank. 2003. The Founding Fathers and the Place of Religion in America. Princeton: Princeton University Press. Lee, Daniel, and Joseph Frost. 1844. Ten Years in Oregon. New York: J. Collard.

Marty, Martin. 1987. Religion and the Republic: The American Circumstance. Boston: Northeastern University Press.

McGuiness, Aims. 2003. Searching for 'Latin America:' Race and Sovereignty in the Americas in the 1850s. In Race and Nation in Modern Latin America. Edited by Nancy P. Applebaum. Chapel Hill: University of North Carolina Press. 
Miller, Howard. 1988. Stephen F. Austin and the Anglo-Texan Response to the Religious Establishment in Mexico, 1821-1836. Southwestern Historical Quarterly 91: 283-316.

Moore, Ely. 1833. Authentic Biography of Col. Richard M. Johnson of Kentucky. Boston: Henry Mason.

Michael Morrison, and James Brewer Stewart, eds. 2002. Race and the Early Republic: Racial Consciousness and Nation Building in the Early Republic. Lanham: Rowman and Littlefield.

Niezen, Ronald. 2000. Spirit Wars: Native North American Religions in the Age of Nation Building. Berkeley: University of California Press.

Noll, Mark. 2008. God and Race in American Politics: A Short History. Princeton: Princeton University Press.

Ostler, Jeffrey. 2004. The Plains Sioux and U.S. Colonialism from Lewis and Clark to Wounded Knee. Cambridge: Cambridge University Press.

Pagliarini, Maria Anne. 1999. The Pure AmericanWoman and the Wicked Catholic Priest: An Analysis of Anti-Catholic Literature in Antebellum America. Religion and American Culture 9: 97-128. [CrossRef]

Pierce, George F. 1857. Incidents of Western Travel: In a Series of Letters. Nashville: Stevenson and Owen.

Pinheiro, John C. 2014. Missionaries of Republicanism: A Religious History of the Mexican-American War. New York: Oxford University Press.

Roediger, David R. 1997. The Wages of Whiteness: Race and the Making of the American Working Class. London: Verso.

Schmidt, Leigh Eric. 2002. Hearing Things: Religion, Illusion, and the American Enlightenment. Cambridge: Harvard University Press.

Schueller, Malini Johar. 2003. Nation, Missionary Women, and the Race of True Womanhood. In Messy Beginnings: Postcoloniality and Early American Studies. Edited by Malini Johar Schueller. New Brunswick: Rutgers University Press.

Smith, Christopher. 2003. The Secular Revolution: Power, Interests, and Conflict in the Secularization of American Public Life. Berkeley: University of California Press.

Smoak, Gregory E. 2006. Ghost Dances and Identity: Prophetic Religion and American Indian Ethnogenesis in the Nineteenth Century. Berkeley: University of California Press.

Stephanson, Anders. 1995. Manifest Destiny: American Expansion and the Empire of Right. New York: Hill and Wang.

Takaki, Ronald. 1998. Strangers from a Different Shore: A History of Asian Americans. Berkeley: University of California Press.

United States Congress. 1887. Report of the Joint Special Committee of the Senate and House of Representatives to Investigate Chinese Immigration. Washington: United States Congress.

van der Veer, Peter, and Hartmut Lehmann. 1999. Nation and Religion: Perspectives on Europe and Asia. Princeton: Princeton University Press.

Weiner, Isaac. 2013. Religion Out Loud: Religious Sound, Public Space, and American Pluralism. New York: NYU Press. Wenger, Tisa. 2009. We Have a Religion: The 1920s Indian Dance Controversy and American Religious Freedom. Chapel Hill: University of North Carolina Press.

Whitman, Narcissa. 1986. The Letters of Narcissa Whitman. Fairfield: Ye Galleon Press.

Wong, Chin Foo. 1887. Why I am a Heathen. North American Review 145: 177.

Wong, K. Scott. 1998. Cultural Defenders and Brokers: Chinese Responses to the Anti-Chinese Movement. In Claiming America: Constructing Chinese American Identities During the Exclusion Era. Edited by K. Scott Wong and Sucheng Chan. Philadelphia: Temple University Press.

(C) 2017 by the author. Licensee MDPI, Basel, Switzerland. This article is an open access article distributed under the terms and conditions of the Creative Commons Attribution (CC BY) license (http://creativecommons.org/licenses/by/4.0/). 